\title{
Psychosocial approaches to neoliberal policies, welfare institutions and practices in the Nordic welfare states
}

\author{
Lundgaard Andersen, Linda; Dybbroe, Betina
}

Published in:

Journal of Psycho-Social Studies

DOI:

10.1332/147867320X15982855867251

Publication date:

2020

Document Version

Peer reviewed version

Citation for published version (APA):

Lundgaard Andersen, L., \& Dybbroe, B. (2020). Psychosocial approaches to neoliberal policies, welfare institutions and practices in the Nordic welfare states. Journal of Psycho-Social Studies, 13(3), $225-233$. https://doi.org/10.1332/147867320X15982855867251

\section{General rights}

Copyright and moral rights for the publications made accessible in the public portal are retained by the authors and/or other copyright owners and it is a condition of accessing publications that users recognise and abide by the legal requirements associated with these rights.

- Users may download and print one copy of any publication from the public portal for the purpose of private study or research.

- You may not further distribute the material or use it for any profit-making activity or commercial gain.

- You may freely distribute the URL identifying the publication in the public portal.

\section{Take down policy}

If you believe that this document breaches copyright please contact rucforsk@kb.dk providing details, and we will remove access to the work immediately and investigate your claim. 


\section{Journal of Psychosocial Studies \\ Psychosocial approaches to neoliberal policies, welfare institutions and practices in the Nordic Welfare States \\ Editorial \\ --Manuscript Draft--}

\begin{tabular}{|c|c|}
\hline \multicolumn{2}{|l|}{ Manuscript Number: } \\
\hline Article Type: & Academic Article \\
\hline Keywords: & $\begin{array}{l}\text { Psychosocial } \\
\text { neoliberal practices } \\
\text { intersubjectivity } \\
\text { collectivity }\end{array}$ \\
\hline Corresponding Author: & $\begin{array}{l}\text { Linda Lundgaard Andersen, Ph.D. } \\
\text { Roskilde Universitet } \\
\text { Roskilde, DENMARK }\end{array}$ \\
\hline Order of Authors: & Betina Dybbroe \\
\hline Abstract: & $\begin{array}{l}\text { The special issue chapters aim to delve deeper into how neoliberalism presents itself } \\
\text { in welfare practices and institutional settings, with a special interest in how human } \\
\text { agency, subjective experience and identities, as well as intersubjectivity and collective } \\
\text { life, are affected. This invitation has led to interesting new research contributions from } \\
\text { scholars addressing a varied spectrum of welfare institutions, practices and problems. } \\
\text { Guiding all the contributions has been an ambition to understand and demonstrate how } \\
\text { the subjective and intersubjective lives of professionals and citizens are affected by } \\
\text { neoliberalism in ways that change the practices of care, rehabilitation, social work, } \\
\text { health promotion and learning, in addition to the participation and living of citizens in } \\
\text { contact with welfare institutions. }\end{array}$ \\
\hline
\end{tabular}




\section{Cover Page}

Special issue // Journal of Psychosocial Studies

Psychosocial approaches to neoliberal policies, welfare institutions and practices in the Nordic Welfare States

\section{Editorial}

Linda Lundgaard Andersen and Betina Dybbroe 


\section{Special issue // Journal of Psychosocial Studies}

\section{Psychosocial approaches to neoliberal policies, welfare institutions and practices in the Nordic Welfare States}

\section{Editorial}

Linda Lundgaard Andersen and Betina Dybbroe

Controversy over the neoliberalization of policy and practice in welfare contexts is alive and active in many national and international settings. Neoliberalism in welfare societies and contexts is supported by a shift towards governance at all levels of modern societies, affecting how welfare is designed, managed and practiced. Critical welfare research has since the beginning of the century demonstrated how welfare systems have become market driven, and how accountability and economic rationalities challenge the universalistic and redistributive aims of Nordic welfare systems (Christensen, 2012; Dahl, 2009; Vabø, 2006). Social and policy researchers have further pointed to how neoliberalism increases segregation in European societies today (Wacquant, 2009) and spreads elitist ideas about radical individual freedom (Trägårdh, 2018).

Over time, the space for critical knowledge in welfare services has become limited, whereas the need to present critical knowledge has grown. This special issue is such an endeavour, where we present new Nordic analyses of welfare systems and practices influenced by neoliberalism. Neoliberalism has traditionally been theorized as a policy framework, ideology and/or governance. However, we should be careful not to underestimate the significance of contemporary transformations in neoliberal governance. Neoliberalism is both a political discourse about the nature of ruling and also a set of practices that facilitate from a distance (Larner, 2000). What is labelled neoliberalism also draws on more generalized elitist ideas of what it is to be a citizen, such as radical individual freedom (Trägårdh, 2018) as well as class and ethnic differentiation (Wacquant, 2009).

In the spirit of the market, welfare institutions and services have been transformed into production and commercial units, selling and buying services. Currently, we see how market rationality of welfare policies and services has become dominant in welfare planning, and how welfare has been politically designed and operationalized through the rationality of economic cost effectiveness and standardized production. Neoliberal policies and economic theory argue for and justify these practices (Friedman, 1994), while political debates on the provision of services that societies and citizens need, request and envisage are marginalized. The widespread presence and power of neoliberalism as an ideology is by critical policy and social researchers not seen to lie in its economic programme, but rather in its ability to conquer and dominate thinking about social development. Neoliberalism depoliticizes political transformations and performs as a normative basis, creating boundaries for what is of value, and what is not, in society (Boltanski and Chiapello, 2006; Burnham, 1999) Stahl 2018).

At the start of the millennium, several European countries displayed a political interest in various forms of resistance and articulation of voices from professionals and users. Social and health care workers have criticized the effects of New Public Management, and user movements asked for inclusion of citizens and 
users in the forming of welfare institutions (Barnes and Cotterell, 2012; Dahl, 2009; Newman and Tonkens, 2011). As of today, user involvement policies are mainstream in welfare institutions, but largely as a means of involving citizens in taking responsibility for co-producing or co-creating welfare. Nevertheless, segregation has deepened as many citizens are unequally positioned, and many are without influence on welfare planning and management (Protheroe, Brooks, Chew-Graham, Gardner, and Rogers, 2013)(Protheroe et al., 2013). Currently, we see a persistent diminishment of state responsibility for welfare, and a development towards "welfare pluralism" encompassing the state, private entrepreneurs and the voluntary sector, which changes the state responsibility for welfare of all (Dahlberg, 2005; Enjolras and Strømsnes, 2017).

\section{Self-optimizing entrepreneurs or agencies of feelings, desires and subconscious drives}

It has been suggested by critical research that subjects become self-optimizing entrepreneurs investing in their own capital (Petersen and Lupton, 1996) and neoliberalism becomes a form of generalized normativity of competition and entrepreneurship that encompasses both governed and governing (Foucault, Davidson, and Burchell, 2008). The entrepreneur and entrepreneurialism are essential to the success of the marketplace, while the dissemination of the discourses of the entrepreneur and of entrepreneurialism is pivotal to the spread of a neoliberal agenda and the subsequent marketization of the sectors (Sandberg, 2016). These processes are said to have permeated the welfare services, and govern institutional practices and interactions between professionals and citizens. Clearly, the Danish and Nordic welfare states have been permeated by a much more entrepreneurial discourse and practice than previously (Andersen, 2018; Kamali and Jönsson, 2018). However, the rationalities of self-optimization and consumerism are also met and challenged by meaning making at inter-relational and practice levels. Other rationalities such as the commitment to community and human obligation (Gibson-Graham, 2014; Mendell and Alain, 2015), and the logic of care (Mol, 2008; Waerness, 1984) also contribute to forming practices.

The cultural and human dimensions of welfare practices and work are present as socializing and acknowledging dimensions of life. In our research we have identified how welfare institutions also comprise scenes and spaces for subjective and intersubjective identification and recognition (Andersen and Dybbroe, 2017). In human service, such as social and health care, the citizens, patients and clients involved are a significant dimension of working life, social interaction and the creation of meaning. Interactions between citizens, clients, patients and service providers become formative for the development of professional thinking and identity. Welfare settings must also be understood as "human meeting places" with a wider scope, and as humanizing learning spaces. In these meeting places we see agency, feelings and emotions, desires and subconscious drives and motives unfolding, which serve as drivers for both professional and civic encounters.

A more rounded understanding of the complex human agencies involved must form the basis for developing a critical analysis of neoliberal practices that does not rest on suggesting governing and governed subjects as ciphers for the onward march of neoliberalism. Thus, in this special issue we are interested in exploring how subjectivity, intersubjectivity and collectivity are present in welfare settings in relation to neoliberal norms, values and frameworks. We seek to provide deeper psychosocial knowledge of how neoliberal policies and practices influence and become active and dominant in transformed practices of welfare - at subjective, intersubjective and institutional levels. We set out to explore how neoliberal values and policies may institute individualization, vulnerability and shame in situations of human life undergoing change, and how collective 
responsibility thus decreases. Moreover, we are interested in analysing welfare services in transformation that enable representations of subjectivity and intersubjectivity informed by psychosocial understandings. At the heart of this is an understanding of welfare development as complex processes of control and resistance, retrenchment and innovation, discipline and humanization in the intersections of policies and human practices. Our endeavour is consequently to enhance knowledge of how neoliberal policies, ideals and practices transform and become active and dominant, or are refused and circumvented, in practices of welfare that reflect micro and macro levels.

\section{Psychosocial theorization on neoliberal practices}

Psychosocial theory has deepened our understandings of neoliberally influenced subjective and intersubjective practices. Layton points out how neoliberalism promotes the development of certain versions of subjectivity, certain character structures, defences, transferences, and countertransference (Layton, 2014). Hoggett explains how performativity exploits the employee's desire to achieve the ideal, using target setting and performance monitoring, leading to insecurity, failure and feelings of shame (Hoggett, 2017). Glynos suggests how policies that aim to maximize market competition amplify splitting tendencies in subjects that subscribe to particular fantasies such as 'Individual Self-Sufficiency' or dependence fantasies of the 'Caring Other' (Glynos, 2014). Fotaki points out how market-based freedom of choice and user autonomy relies on, and taps into, unconscious dynamics and fantasies of invincibility, while ignoring the precariousness of life and our infinite potential to experience vulnerability. This creates toxicity in organizations, thus corrupting the moral institutional fabric (Fotaki, 2017).

Our readings of New Public Management in Danish welfare services have found that marketization and consumerism have led to anxiety, ambivalence, aggression and other forms of defence in professional interactions. On the one hand, current welfare work situates a skilled and devoted professional to direct performative processes and outcomes based on personalized identification, often in collaboration with citizens. The meaning of work for welfare workers is not based just on procedures and standards, technical skills and time, but is created materialistically and psycho-socially in practice, when tasks are performed and interactions shape care, social work etc.- and include others, as intersubjective meaning (Dybbroe, 2011). On the other hand, a number of ambivalences and defensive reactions saturate the very same processes and outcomes (Andersen, 2003, 2016). We point out how target-driven practice and evidential monitoring in hierarchical structures remove the focus from professional reasoning and understanding, consequently diminishing the qualifying processes of introspection in and on practice. The troubling and uneasy dimensions of work become unspeakable and marginalized, whereas the organizations will focus on rational language and the practice of measurable targets and objectives (Andersen and Dybbroe, 2017). In the workplaces of welfare practices we have seen how social dynamics interact with individual and life historical subjective dynamics in ways that illuminate not only habitual and creative orientations and practices of professionals, but also the contradictory transformations of work, e.g. of marketization and democratization (Dybbroe, 2013).

The theoretical framings in this special issue span a variety of psychosocial conceptualizations drawing upon (some of) the scholarly work from psychoanalytic social psychology rooted in critical theory (Bereswill, Morgenroth, and Redman, 2010; Leithäuser, 2012, 2013; Leithäuser, Meyerhuber, and Schottmayer, 2009; Leithäuser and Volmerg, 1988; Lorenzer, 1986), the Tavistock tradition (Menzies Lyth, 1988), object relations 
theory (Bion, 1962; Ferenczi, 1955), ego psychology (Freud, 1966) and the psy-sciences approach (Borgos, Gyimesi, and Erős, 2019). Harvesting from the chapters and acknowledging the differences and specificities of the theoretical landscape, we nevertheless notice a shared endeavour of critical readings of human and societal phenomena and manifestations, which not only probes into subtle, hidden and latent meanings. But also holds an interest in the relation between culturally shared emotions and psychic landscapes- and developments at societal level. Richards suggests a psychosocial 'binocularity' that transgresses the monocular application of psychological or sociological theory to social phenomena, arguing that "the sociohistorical context might somehow shape the mind, and facilitate the development or strengthening of some psychic organisations or complexes over others" (Richards, 2019, p. 180). Leithäuser and Volmerg ask a similar question: "in which ways do societal factors establish themselves in psychological structures and how are they transformed into regulatory mechanisms? And the reverse movement: how do psychological drives, wishes and needs support and connect to social and societal roles and situations in a search for gratification?" (Leithäuser and Volmerg, 1988, p. 10). These ambitions we see as pivotal for unlocking neoliberal practices in a psychosocial perspective.

\section{Chapter introduction}

The special issue chapters aim to delve deeper into how neoliberalism presents itself in welfare practices and institutional settings, with a special interest in how human agency, subjective experience and identities, as well as intersubjectivity and collective life, are affected. This invitation has led to interesting new research contributions from scholars addressing a varied spectrum of welfare institutions, practices and problems. Guiding all the contributions has been an ambition to understand and demonstrate how the subjective and intersubjective lives of professionals and citizens are affected by neoliberalism in ways that change the practices of care, rehabilitation, social work, health promotion and learning, in addition to the participation and living of citizens in contact with welfare institutions.

In Social innovation in welfare practices: Identification, idealization and shame, Linda Lundgaard Andersen states that social innovation is the new lingo that permeates welfare service. The chapter provides insight into the psychosocial fabric of this current development, pointing out how identification, idealization and shame become descriptive of the psychosocial landscapes in social enterprises. Departing from case studies it is illustrated how managers and staff identify with and idealize their social innovative missions, but find it difficult to fulfil their aspirations in the face of (neoliberal) societal and organizational contexts and conditions.

In Loneliness and lost community in the scenes of elderly care, Betina Dybbroe analyses how care for the very old and fatally ill in home based care in Nordic societies presently is characterised by identifications, sensing and projections of the fear of loneliness and risk of dying, and the longing for community. The neoliberal ideals of individual living, individual choice and person-centred care guide practices but are contradicted by the uniformity and the austerity of care provision. The vulnerability when facing death, and the societal neoliberal construction of the autonomous subject, creates projections of emotions of fear and risk in professionals, but also fantasies about community and shared vulnerability.

Emotional processes in a struggling nursery in neoliberal times by Thomas Gitz-Johansen explores the influence of political and institutional conditions on the emotional life of staff in a public day-care nursery for 
0-2 year old children, exposed to New Public Management. The analysis shows how the emotional life of the professionals is characterised by processes of suppressing the needs of very small children, and projective identification of feelings onto other staff members. The emotional reactions of the professionals, however, become illuminated through the sensing of the researcher, and the article reflects on the suppression of emotions in the care of small children, influenced by a neoliberal construction of small children as learners.

In Unemployment, learning, subjectivity and experience in times of neoliberal employment policy, Mikkel Bech Morgen analyses how learning as an aspect of the individual's life historical experiential processes is affected by the neoliberal organization of the employment system and back-to-work policies and practices. This leads to ambiguities and by reflecting the life history of one individual case, the chapter demonstrates how this fosters a lack of experience, self-alienation and defensive self-preserving psychodynamics.

Neoliberal conduct through moral class anxiety; risk, responsibilization and the fear of falling by Iben Aamann illuminates how a psychosocial approach to class sheds light on the ways in which neoliberal governmentality works through a "regime of judgments" rooted in class relations. Drawing upon cases of health and two different mothers involved in their children's preschool classes, the chapter concludes how class morals currently shape subjectivity and how the emotional implications of this are the drivers of the ways in which neoliberal governmentality relies on moral judgments related to healthism, risk and responsibilization.

In Categorization of students with psychosocial problems - the messiness of shame and belonging in higher education by Trine Wulf-Andersen and Lene Larsen, mental health is seen as a new sorting mechanism in higher education, working through categories informed by psychological and psychiatric knowledge. This chapter discusses how certain categorizations and understandings of students' well-being and everyday problems, inspired by the psy-sciences, intertwine with neoliberal traits in educational institutions. This mediates students' emotional and educational experience leading to feelings of shame and unworthiness related to inequality in education.

Couldn't care less? The integrated breast cancer pathway as a psychosocial case. A threat to care ethics in specialist healthcare? by Birgitta Haga Gripsrud, Ellen Ramvi and Bjørn Ribers focuses on contemporary breast cancer care as an area of clinical practice that has undergone a policy-driven transformation in the form of 'integrated patient pathways'. This framework may challenge quality of care and the chapter introduces a psychosocial understanding of care that is sensitive to the intersubjective affects and vulnerabilities in cancer treatment that become exempted from care pathways.

The authors of this special issue have all contributed with new readings of empirical work through a psychosocial lens, often drawing on sociological theory, and addressing the cultural and societal transformations that frame everyday practices in various sectors of welfare, whether social services, health care, educational settings or employment services. Emotionality appears as a pivotal and integral part of professional encounters and the contributions probe into defended identifications of selves and others. The chapters contribute to neoliberal readings of how New Public Management has been implemented in Denmark and Norway, and suggest different welfare scenarios of how we can identify policies and practices. While emotionality is of great significance in the targeted settings and institutions, several authors in their chapters detect a loss of language and legitimacy regarding emotions that seems to be connected to neoliberal values and its political frameworks (Andersen, Gitz-Johansen, Dybbroe). This necessarily represents an obstacle to research, but the authors also provide insights into how they involve themselves, and are affected emotionally, as key to understanding the intersubjective practices and reflecting on the 
defence mechanisms against neoliberal transformations (Gitz-Johansen, Dybbroe). Moreover, we see a focus on the effects of categorizing, segregating and classing subjectivities related to neoliberal practices in several analyses (Morgen, Wulf-Andersen and Larsen, Aamann, Gripsrud, Ramvi and Ribers). The fear of expulsion from collectivity and the sense of losing relationships and access to others is a guiding theme in several of the contributions (Andersen, Dybbroe, Morgen, Wulf-Andersen and Larsen). One of the interesting crosscutting findings of the presentations is how shame, alienation, exclusion and loneliness become active through transferences and countertransferences in welfare practices. Finally the chapters provide insight into how subjects create meaning and identification by following other rationalities, i.e. those of care, community, dignity and human growth, in neoliberal times.

\section{References}

Andersen, L. L. (2003). When the unconscious joins the game: A psychoanalytic perspective on modernization and change. Forum Qualitative Sozialforschung, 4(3), 1-13.

Andersen, L. L. (2016). A psycho-societal perspective on neoliberal welfare services in Denmark : Identification and ambivalence. Journal of Psycho-Social Studies, 9(1), 94-109.

Andersen, L. L. (2018). Neoliberal drivers in hybrid civil society organisations: Critical readings of civicness and social entrepreneurism. In Masoud Kamali and J. H. Jönsson (Eds.), Neoliberalism, Nordic Welfare States and Social Work (pp. 43-52). Routledge.

Andersen, L. L., and Dybbroe, B. (2017). Introspection as intra-professionalism in social and health care. Journal of Social Work Practice, 31(1), 21-35. https://doi.org/10.1080/02650533.2016.1142952

Barnes, M., and Cotterell, P. (2012). Critical perspectives on user involvement. Policy Press.

Bereswill, M., Morgenroth, C., and Redman, P. (2010). Alfred Lorenzer and the depth-hermeneutic method. Psychoanalysis, Culture and Society, 15(3), 221-250. https://doi.org/10.1057/pcs.2010.12

Bion, W. R. (1962). Learning fom experience.

Boltanski, L., and Chiapello, È. (2006). Der neue Geist des Kapitalismus. BoD-Books on Demand.

Borgos, A., Gyimesi, J., and Erős, F. (2019). Psychology and Politics: Intersections of Science and Ideology in the History of Psy-sciences. CEU Press.

Burnham, P. (1999). The politics of economic management in the 1990s. New Political Economy, 4(1), 3754.

Christensen, K. (2012). Towards a mixed economy of long-term care in Norway? Critical Social Policy, 32(4), 577-596. https://doi.org/10.1177/0261018311435028

Dahl, H. M. (2009). New Public Management, care and struggles about recognition. Critical Social Policy, 29(4), 634-654. https://doi.org/10.1177/0261018309341903

Dahlberg, L. (2005). Interaction between voluntary and statutory social service provision in Sweden: a matter of welfare pluralism, substitution or complementarity? Social Policy and Administration, 39(7), 740-763.

Dybbroe, B. (2011). The Meaning of Work in Subjective and Intersubjective Perspective: A daily conflict of creating and loosing meaning in elderly care. In Elderly care in transition (pp. 133-164). Copenhagen 
Business School Press.

Dybbroe, B. (2013). Work identity and contradictory experiences of welfare workers in a life-history perspective. Historical Social Research/Historische Sozialforschung, 13(3), 107-123.

Enjolras, B., and Strømsnes, K. (2017). Scandinavian Civil Society and Social Transformations : The Case of Norway. (B. Enroljas and K. Strømness, Eds.). Springer.

Ferenczi, S. (1955). Final contributions to the problems and methods of psychoanalysis. Basic Books.

Fotaki, M. (2017). Relational ties of love-A psychosocial proposal for ethics of compassionate care in health and public services. Psychodynamic Practice, 23(2), 181-189.

Foucault, M., Davidson, A. I., and Burchell, G. (2008). The birth of biopolitics: lectures at the Collège de France, 1978-1979. Palgrave Macmillan.

Freud, A. (1966). The Writings of Anna Freud, Vol. II (1936): The Ego and the Mechanisms of Defense. New York, NY: International Universities Press.

Friedman, J. (1994). Cultural identity and global process (Vol. 31). Sage.

Gibson-Graham, J. K. (2014). Rethinking the Economy with Thick Description and Weak Theory. Current Anthropology, 55(S9), S147-S153. https://doi.org/10.1086/676646

Glynos, J. (2014). Neoliberalism, markets, fantasy: The case of health and social care. Psychoanalysis, Culture and Society, 19(1), 5-12. https://doi.org/10.1057/pcs.2013.23

Hoggett, P. (2017). Shame and performativity: Thoughts on the psychology of neoliberalism. Psychoanalysis, Culture and Society, 22(4), 364-382. https://doi.org/10.1057/s41282-017-0050-3

Kamali, M., and Jönsson, J. H. (2018). Neoliberalism, Nordic welfare states and social work: Current and future challenges. Routledge.

Larner, W. (2000). Neo-liberalism: Policy, Ideology, Governmentality. Studies in Political Economy, 63, 5-25. https://doi.org/10.1057/9780230800892_11

Layton, L. (2014). Some psychic effects of neoliberalism: Narcissism, disavowal, perversion. Psychoanalysis, Culture and Society, 19(2), 161-178.

Leithäuser, T. (2012). FORUM : QUALITATIVE SOCIAL RESEARCH Psychoanalysis, Socialization and Society The Psychoanalytical Thought and Interpretation of Alfred Lorenzer 1 . Alfred LORENZER at the University of Bremen - A Personal Foreword, 13(3).

Leithäuser, T. (2013). Psychoanalysis, socialization and society. The psychoanalytical thought and Interpretation of Alfred Lorenzer. Historical Social Research/Historische Sozialforschung, 56-70.

Leithäuser, T., Meyerhuber, S., and Schottmayer, M. (2009). Sozialpsychologisches Organisationsverstehen. Wiesbaden: VS Verlag für Sozialwissenschaften.

Leithäuser, T., and Volmerg, B. (1988). Psychoanalyse in der Socialforschung. Eine Einführung am Beispiel einer Socialpsychologie der Arbeit. [Psychoanalysis in social research. An introduction to the example of a social psychology of work] Westdeutscher Verlag.

Lorenzer, A. (1986). Tiefenhermeneutische Kulturanalyse. Kultur-Analysen, 1, 11-98.

Mendell, M., and Alain, B. (2015). Enabling the social and solidarity economy through the co-construction of public policy. In P. Utting (Ed.), Social and solidarity economy: Beyond the fringe (pp. 166-184). 
Menzies Lyth, I. (1988). Containing Anxiety in Institutions. London: Free Associations Books.

Mol, A. (2008). The logic of care: Health and the problem of patient choice. Routledge.

Newman, J., and Tonkens, E. (2011). Participation, Responsibility and Choice. Summoning the Active Citizen in Western European Welfare States. Introduction. (J. Newman and E. Tonkens, Eds.). Amsterdan University Press.

Petersen, A., and Lupton, D. (1996). The new public health: Health and self in the age of risk. Sage Publications, Inc.

Protheroe, J., Brooks, H., Chew-Graham, C., Gardner, C., and Rogers, A. (2013). 'Permission to participate?'A qualitative study of participation in patients from differing socio-economic backgrounds. Journal of Health Psychology, 18(8), 1046-1055.

Richards, B. (2019). Beyond the angers of populism: a psychosocial inquiry. Journal of Psychosocial Studies, 12(1), 171-183. https://doi.org/10.1332/147867319x15608718111014

Sandberg, B. (2016). Against the Cult(ure) of the Entrepreneur for the Nonprofit Sector. Administrative Theory and Praxis, 38(1), 52-67. https://doi.org/10.1080/10841806.2015.1130524

Trägårdh, L. (2018). Scaling up Solidarity from the National to the Global. In Sustainable Modernity (Vol. 79, pp. 79-101). ROUTLEDGE in association with GSE Research.

Vabø, M. (2006). Caring for People or Caring for Proxy Consumers? European Societies, 8(3), 403-422. https://doi.org/10.1080/14616690600821990

Wacquant, L. (2009). Punishing the poor: The neoliberal government of social insecurity. duke university Press.

Waerness, K. (1984). The rationality of caring. Economic and Industrial Democracy, 5(2), 185-211. 